\title{
Indigenous People and the Preservation of Biodiversity
}

\author{
Robert E. Rhoades ${ }^{1}$ \\ Department of Anthropology, University of Georgia, Athens, GA 30602
}

Distinguished officers, members, and guests of the American Society for Horticultural Science. It is indeed a great honor to deliver the 7th Annual William A. "Tex" Frazier Lecture. The boldly innovative notion that a science can learn from other disciplines should be replicated throughout the scientific community. Solving world food and environmental problems will, by their very nature, require interdisciplinary teamwork. I congratulate you.

\section{CHECKING OUT AT THE COUNTER: AN ANTHROPOLOGICAL JOURNEY}

This afternoon I want to take you on an anthropological journey, but not to the world most of us think about when we hear the word "anthropology." My discipline has a reputation for revealing bizarre customs that shock our Occidental standards or for revolting descriptions of exotic foods such as chocolatecovered ants and fried scorpions. This expedition instead sets out on a trail linking Western agricultural science and the often forgotten native peoples living in distant lands who are, by all measures, the unheralded guardians of Earth's plant genetic treasures.

Assume for a moment that before us is a shopping cart laden with the typical fruits, vegetables, and grains we regularly purchase every time we go to the grocery store. As we watch each item being "checked," let us play a little mind game called "Name-the-Place-ofOrigin" or "Where-was-this-Plant-Domesticated?" As horticulturists you know that these apples originate from the Black Sea, sweetpotatoes from the Caribbean or perhaps Peru, beans from Mexico, rice from northeastern India or Thailand, lettuce from the Near East, corn from Mexico, oranges from China, grapes from Afghanistan, potatoes from Peru, bell peppers from Mexico, bananas from Malaysia and Philippines, and coffee from Ethiopia.

By now, you have noticed a clear pattern in our origins quiz. We could not identify a single true-blooded North American in the whole cart. There is this one small bag, labeled "American crops," with some sunflower seeds, Jerusalem artichokes, raspberries, cranberries, blueberries, and pecans. Delicious little morsels and economically mighty important, you might say, but pretty slim pickings if we had to depend on them for day-to-day nutrition. In fact, probably less than $2 \%$ of our U.S. food supply comes from North American-

Received for publication 31 Aug. 1994. This paper was presented as the William A. (Tex) Frazier Lecture at the 91st Annual Meeting of the American Society for Horticultural Science, Corvallis, Ore., 7 Aug. 1994.

${ }^{1}$ Professor and Head.

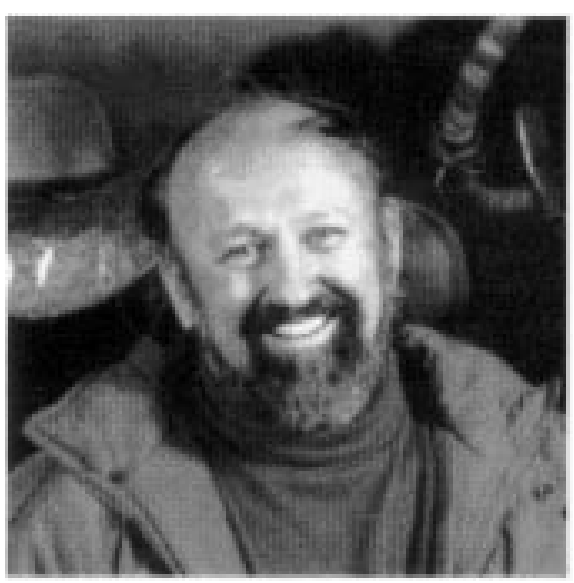

originated crops, the other $98 \%$ originates elsewhere.

But what difference does it make, you might argue, if most of our foods are derived from alien plants, not "made in America"? Doesn't each U.S. farmer produce enough food for 128 people, the highest productivity in the world? Agriculture is our number one industry, and food exports remain the key to our balance of payments.

True. But look again at the shopping cart and think of its contents not as "food," but as the seeds that contain the "germplasm," that mysterious genetic stuff that provides the disease resistance, yield, color, and taste of the next harvest. I do not need to remind this audience that we need a constant and diverse supply of germplasm to maintain the great American farm productivity. Worldwide, a continuous and safe supply of germplasm is mandatory for continued supply of the basic 20 crops that provide $90 \%$ of humanity's food.

\section{IN THE BEGINNING: A FARMING REVOLUTION}

Who are the curators of this diverse germplasm that comes to us in the form of landraces, wild, and semi-wild progenitors? They are native, indigenous peoples living on the margins of our western civilization. Their story begins, as does our anthropological journey, some five to ten millennia ago-depending on the continent-in scattered mountainous locations in Mesopotamia, Meso-America, South America, East Africa and Southeast Asia. For multiple reasons, prehistoric bands of hunters and gatherers began to experiment with and domesticate the grains, tubers, vegetables, and fruits that sustain us today. For example, in the Andes, where I spent the entire 1980s, archaeologists have determined that, around 6000 B.C., migratory bands of Indians gathered and transplanted wild tuberosum species along with other tubers and grains in a long process of learning to select those with desirable characteristics, such as higher yield, resistance to pests and climate stress, and storability.

The potato served as the basis of the Andean civilizations, who venerated and depicted the crop in art and pottery. Along with maize, freeze-dried potatoes were carried by llamas to feed the Inca army, which conquered the Andes from Colombia to Chile, the largest Empire of the world during that epoch. And still today, Quechua-speaking natives of the Andes cultivate more than 8000 different kinds of potatoes alongside a dozen wild and semidomesticated species (Fig. 1).

Traveling 3000 miles northward to Mexico's Tehuacan Valley we discovered the same process had occurred with another Ameri-

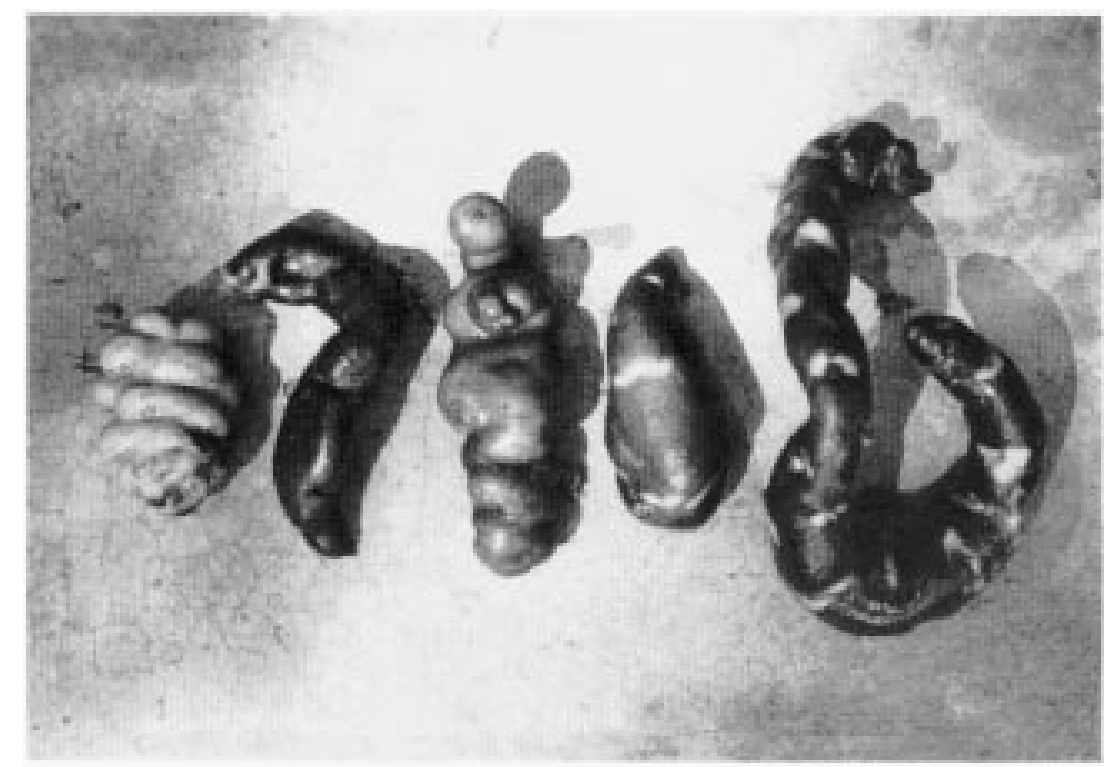

Fig. 1. Five different types of Andean potatoes collected by R.E.R. in Peru. 
can crop known to the Indians as Mahiz"that which sustains life." In Cocaxtlán Cave, my fellow archaeologists uncovered the evolution of corn from 7000 years ago down to the present. After its domestication, probably by women farmers, corn travelled outward at 1 mile per year to the far reaches of the Americas. In new environments and farming systems, corn diversified further into an incredible array of colors, shapes, and genotypes. By the time of Columbus, there were 700 different kinds of popcorns alone. Maize, as did the potato, became the basis of great PreColumbian civilizations, such as the Maya, who still today believe "corn is our blood." Native Americans living in remote Central and South American valleys continue to maintain native reserves of corn germplasm through cultivation of endless varieties.

This same domestication-diversification story was duplicated again and again all over the world: with wheat, rice, barley, fruits, nuts, and hundreds of other food crops. This diversification process was led by farmer-breeders, who, through their own procedures, experimented with crops. At a large amphitheaterlike site called Moray in the Peruvian Andes, archaeologists speculate that early farmers constructed an amazing experiment station with circular terraces that duplicate microclimates and soils of the eastern slopes of the Andes (Fig. 2). Ethnoecologist Harold Conklin found that the Hanunoo of the Philippines identify more than 1600 plant types and some 430 cultivars. Contrast this to the average modern urban dweller who knows only 20 plants.

\section{THE COLUMBIAN EXCHANGE: PLACING THE NORTH ON A FOOD TIGHTROPE}

After the Age of Discovery in the 15th century, conquerors, settlers, slaves, and early sojourners carried plants from their homes and

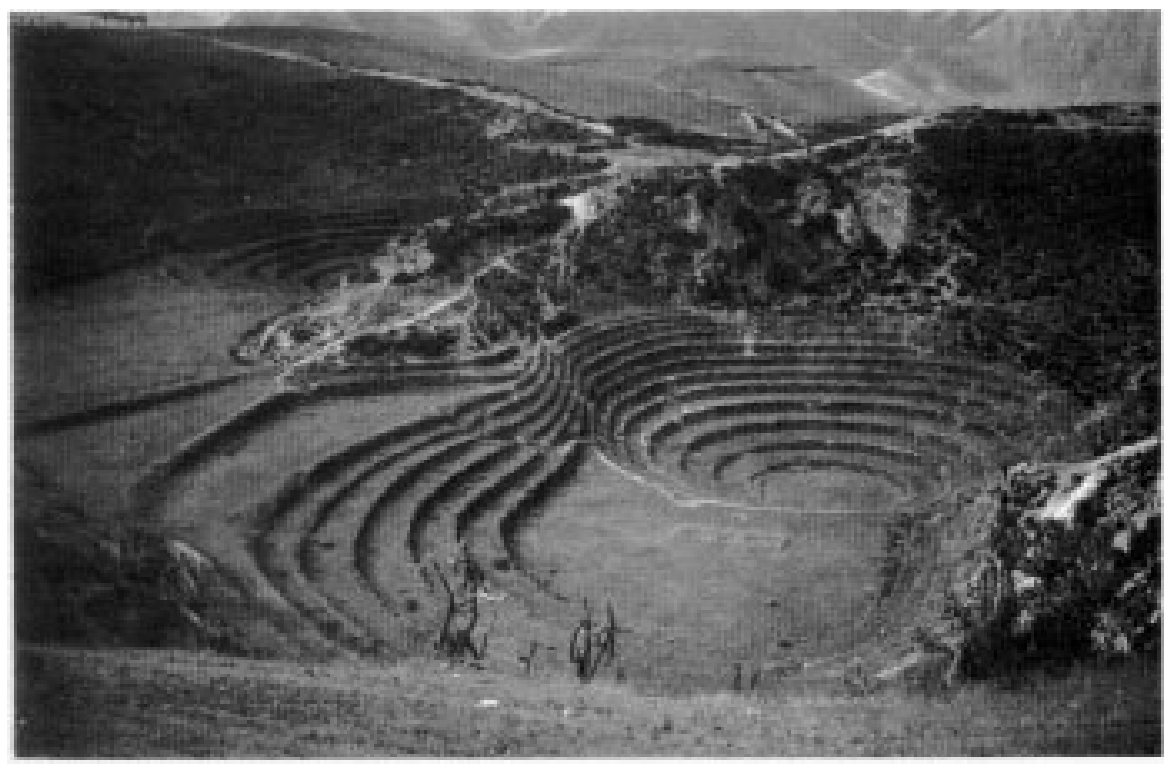

Fig. 2. Archaeologists speculate that this ruin near Macha Pichu, Peru, may have been a pre-Inca experiment station. (photo courtesy of George Wilson)

returned with new ones through a process called the "Columbian Exchange." Some crops, such as the potato, played a key role in providing the surplus food base that made the Industrial Revolution possible. In Ireland, for example, by 1845 the Irish population had exploded to 8 million, more than double the present-day population, with a density greater than modern-day China. The average adult ate 4.5 to $6.8 \mathrm{~kg}$ daily, all from a single strain of potato called "lumper."

While landraces were reaching their maximum diversification in the centers of origin by the late 18th century, a silent "time bomb" ticked away in these exported seeds. Only a small portion of their genetic diversity had been taken from the ancestral land to the new environment, rendering the crops homogenous and thus vulnerable to destruction to disease and climatic vagaries (Fig. 3). Yet, until the late 19th century, the concept of genes, much less genetic resistance or genetic diversity, was not understood by science.

In mid-19th century Europe, a malady mysteriously appeared, a fungus known to us today as late blight (Phytophera infestans), and wiped out the potato crop across Europe. One million Irish perished in a specter that probably resembles the contemporary human catastrophe in Rwanda today. While on a National Geographic Magazine assignment in 1980 (Rhoades, 1982), I visited the Joyce family in County Galway and found the memory of "Black 1847" still etched in the minds of the people. Mrs. Joyce told me that her great-aunt, wholived to be 92 , told her they hauled the bodies in wagons and laid them in pits. There was no money for coffins, nor strength to dig separate graves. They say 5000 Irish died on the way, their bodies thrown into the sea. Farmers today do not like to farm over the old mass graves, although there is no law against it.

Hardly had the people of Europe recovered

from the potato famine when the great vine- 
collected plants because this was the only way to know which plants were valuable. Meyer is credited with introducing more than 2500 new plants into the United States, a feat that changed the American landscape forever. Meyer, for example, brought back the Siberian elm, which, along with the Chinese elm, made up 17,000 miles of windbreaks planted between 1935 and 1942 on the Great Plains. On a recent collecting expedition with the U.S. Dept. of Agriculture (USDA), I learned that Meyer brought back not only the trees, but also the Siberian farmer's idea of the windbreak.

I had the unique honor a few years ago to be able to search out the surviving members of the age of "Great Plant Hunting," those dedicated ethnobotanists who, during the first half of this century, risked their lives to collect in distant lands. From them I learned the central importance of the "native curators" in identifying the cultural value of plants for the foreign collectors.

Asia's greatest botanist was Ahmed Kosterman, who, at the age of 90, was still going strong when I visited him in 1989 at the Bogor Botanical Gardens where he makes his home. A Dutch national at the outbreak of World War II, Kosterman was captured by the Japanese and sent to build the bridge over the River Kwai. Twenty thousand of his fellow prisoners died, but Kosterman lived by learning about locally available herbal and medicinal plants from indigenous Thai tribal populations living along the river. These plants helped Kosterman fight off dysentery and fever.

In South America, the "Great Plant Hunter" is my former colleague, Carlos Ochoa, a Quechua-speaking botanist from Urubamba, Peru, a village in the Sacred Valley of the Inca. $\mathrm{He}$ is truly the Indiana Jones of plant collecting and has combed the Americas in search of wild potatoes, often facing terrorists or hostile foreign authorities who think he is a spy. Ochoa states that he has added more than 1000 new specimens to the world's store of potatoes collected, almost entirely with the assistance of the Indians. The greatest treasures of Ochoa's potatoes cannot be seen so easily. Included among these treasures is the wild potato species with "hairs" that trap aphids, thereby reducing our dependency on pesticides.

Howard Scott Gentry recently passed away, but his legacy will live on in the plants that he rescued from the wild and collected from farmers in places as remote from each other as Iran and Mexico. Howard Scott taught me that you never know the future value of a plant at the time you collect it. The bean collected in Arcelia, Mexico, in the 1950s remained in gene banks until the 1990s, when scientists discovered the "arcelin" gene that carried resistance to bean weevil, a major destroyer of the bean crop in the Third World.

Finally, there is Charley Rick, father of the modern processing tomato, who taught me that wildlife conservation and crops may be more closely linked than we think. He found wild, salt-resistant tomato species in the Galapagos Islands, a possible solution to improving the tomato's productivity in California's increasingly saline soils. When

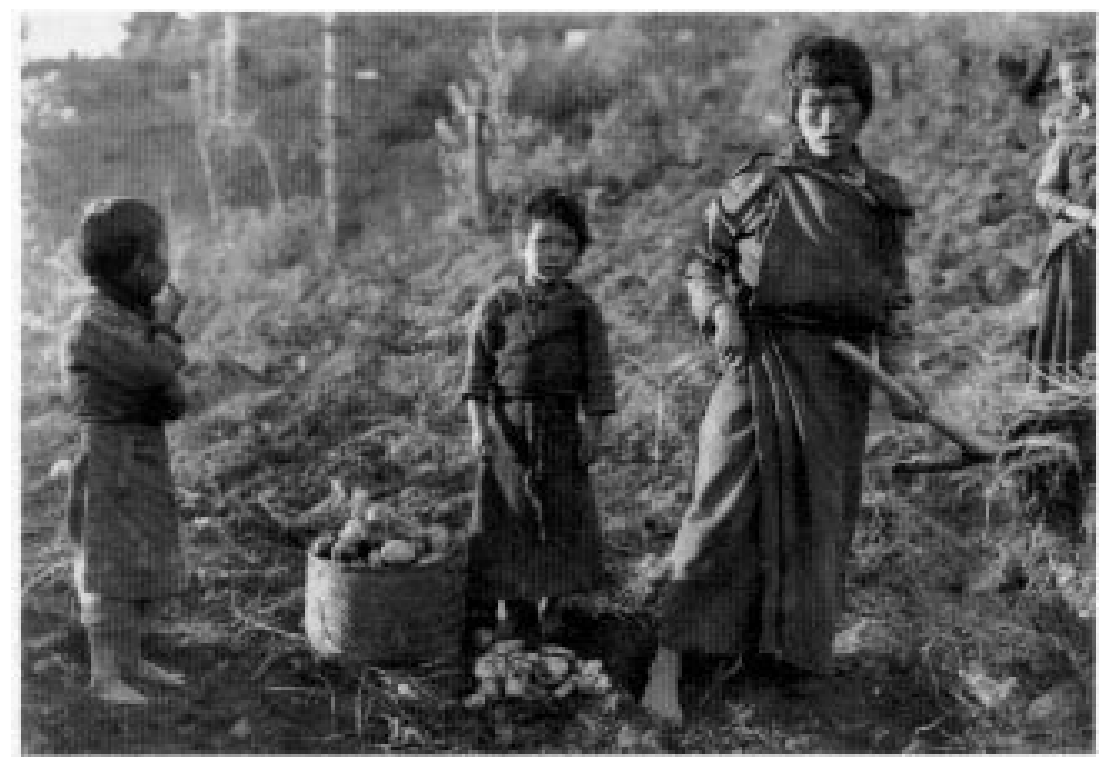

Fig. 3. Potato harvesters in Bhutan where the Andean crop is a recent introduction.

he was unable to germinate wild tomato seeds, he and a friend fed the seed to the nearest Galapagos turtle and got an $85 \%$ germination rate. The lesson is that the survival of this economically important plant is tied to an endangered animal species.

\section{THE AMERICAN CORN BLIGHT: A REALITY BLOW}

Beginning in southern Florida in Winter 1970 , a new virulent fungus suddenly appeared and raced north like a killer flu before fanning out and destroying half the corn crop across the southern United States from Florida to Texas. Nationwide losses amounted to $15 \%$. A box of cereal shot up in price by $300 \%$, total losses amounted to more than one billion dollars and the United States almost became a food-importing nation. The problem was that American corn farmers had sown dense stands of billions of genetically identical kernels.

This event shocked the nation and helped reshape government and public attitudes toward "genetic resources," a term coined only 3 years earlier by Sir Otto Frankel. The government commissioned the National Academy of Sciences to find out how vulnerable the United States really is to crop disaster because of the lack of diversity. The results were shocking: more than half the wheat production depends on a mere nine varieties, three-fourths of our potato crop on four, half of the cotton relies on three varieties, and more than half of our soybean on only six varieties.

\section{GENETIC EROSION AND GENE BANKS}

After the 1970 corn blight, however, when plant collectors went back to collect in Vavilov's centers of origin to replenish the national storehouse of crop diversity, they encountered "genetic erosion." In Greece, for example, wheat varieties declined from 60 in 1930 to four in 1970. In Sri Lanka, rice varieties had declined from more than 2000 in 1960 to only four principal ones today (Fig. 4).

Genetic erosion is the result of global forces related to overpopulation and land-clearing; monocropping with genetically uniform stands of high-yielding, machine-friendly varieties; as well as urbanization and modernization. In my travels to rediscover Vavilov's centers, I came away empty-handed from the same places where seeds had been collected in abundance only a few decades ago.

But what about the gene banks such as those managed by the Consultative Group for International Agricultural Research (CGIAR) and the USDA? With their high-tech solutions, such as cryovats that keep seeds indefinitely at $-196 \mathrm{C}$, aren't they a safeguard against future catastrophes? As valuable as they are for safety values and plant breeding, gene banks are only part of the solution and should

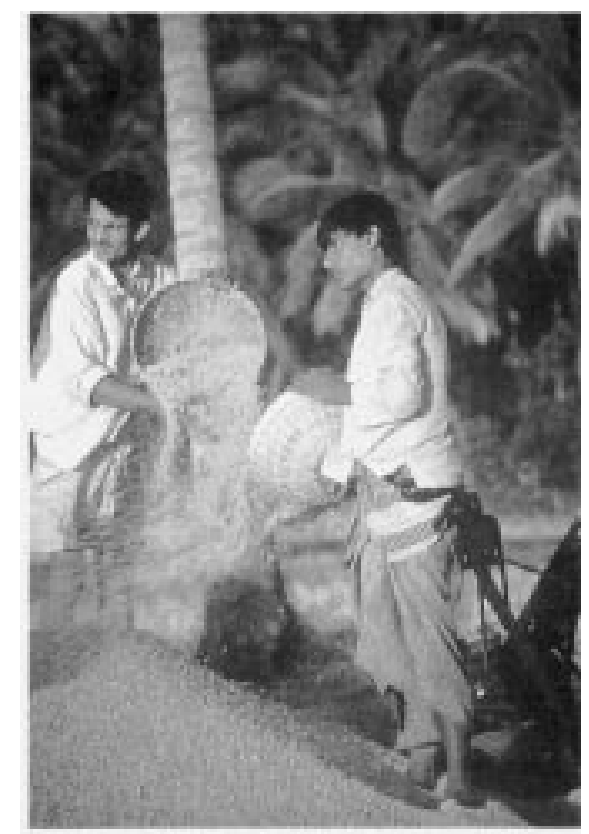

Fig. 4. Harvesting rice in Sri Lanka, where new varieties have pushed out hundreds of valuable landraces. 
be viewed only as a complement to in situ farmer conservation.

First, gene banks hold a small sampling of the genetic material available in nature and farmers' fields. They are not dynamic evolutionary settings. The material is frozen in time or, at most, adapted to a "zoo-like" environment.

Second, gene banks are vulnerable to civil strife and war, and other human or natural calamities. For example, in 1988 in Peru, the International Potato Center World Potato Collection was attacked by "Shining Path Maoists," and one of our guards was killed. We had to rescue the collection by sending duplicates of the accessions to other gene banks.

Third, gene banks are underused. One reason for this underuse is that limited "passport data" (mainly biological and geographical) tells us little about why or where the varieties were planted in the first place. The success story of the International Rice Research Institute's (IRRI) return of Cambodian rice varieties collected before the Khmer reign of terror also points to one of the weaknesses of gene banks. When farmers were forced off the land, knowledge about the traditional Cambodian rices was lost and, thus, few people knew how to plant the varieties that were held in the IRRI gene bank. A great deal of relearning was required by both farmers and scientists.

\section{MEMORY BANKING AND CULTURAL DATA}

In the long-term, laboratory science cannot substitute for in situ conservation where landraces, ancestral lines, and even semidomesticated wild species are cultivated as they have been for centuries by indigenous peoples As genetic erosion proceeds, we also lose valuable indigenous knowledge about the human germplasm heritage.

Traditional methods of maintaining biodiversity is the subject of a research project of the Laboratory of Ethnoecology and Biodiversity, Dept. of Anthropology, Univ. of Georgia. The director, Virginia NazareaSandoval, calls for the systematic documentation of traditional farmers' knowledge into information banks that complement gene banking, a process she labels "Memory Banking." Traditional farmers maintain crop diversity in several ways. They carefully select for desirable characteristics, hold seed fairs to exchange materials, allow wild progenitors to grow along field borders, use true botanical seed to stimulate diversity, and maintain sacred groves. The research has discovered important differences in the way that men and women farmers deal with biodiversity, including sharp perceptual differences in plant characteristics and uses. Another important finding is that maintaining biodiversity is a social as well as an agronomic process. In an attempt to establish a sweetpotato gene bank in the Philippines, male authorities decided on rigid organization (much like a CGIAR gene bank), which collapsed a few months after the project began. The women, using their own informal kin and friendship networks, continued to exchange and diversify genetic material.

However, documentation of this knowledge alone is not sufficient to guarantee its viability in the future. National and international governments must pursue policies that protect and encourage traditional farmers to continue their cultural systems that underpin biodiversity. Particularly important are trade agreements and food import policies that render small farms uneconomical. Unless the gene-poor north awakens to the need to support traditional farmers-instead of extracting genetic resources for selfish ends-political reaction could further close off access to Vavilov's centers of diversity.

Our journey to the world of seeds is not complete if we do not mention efforts in the United States among laypersons - seed savers and home gardeners-who have taken it upon themselves to join hands, network, and preserve both the knowledge and landraces in their own gardens. In northern New Mexico, I met 85-year-old Mr. Talachy, who still saves old seed (hardy barley and garden vegetables) handed down from his grandmother. In Georgia, I have founded the "Rivers of Time" farm, a project to help revitalize a 130-ha degraded cotton farm. My students and colleagues are helping to collect heirloom seeds to revitalize the soil. I encourage all of you to engage in some action, whether it is saving seeds in your garden, writing to Congress about unwise policies, or simply teaching the value of indigenous knowledge and biodiversity.

\section{GENETIC EROSION IN THE GARDEN OF EDEN}

I would like to bring our journey to an end in the place where-at least in our mythology — it all began: the Garden of Eden. Here, between the Tigris and Euphrates rivers, Jack Harlan harvested enough wild grains in the 1960 s with a hand sickle to feed a large village. Today, this same environment is degraded, and the stands of wild grains are found only in scattered oases. But soon, even those genetic treasures may be swept away. The Turkish government is plugging up the rivers with 16 dams for hydroelectric power, simultaneously creating Europe's future breadbasket, an irrigated area the size of Holland and Belgium combined.

Not far from the dam sites I met a peasant who was proud that, in his ancestral graveyard, he could still find the old immer wheats. In my travels, I was often able to collect the most valuable seeds in cemeteries. Is this symbolic of our future?

There are many reasons why we need both the diversity and knowledge of traditional folks. An estimated $40 \%$ of all U.S. drug prescriptions are based on medicinal plants whose efficacious qualities were first identified by native curers. To keep the bloom on our national harvests, our farmers need a constant supply of new genetic material with known resistances. The next generation of farmers will have to produce more food than has been produced since the onset of Neolithic agriculture. Finally, any hopes of conquering outerspace will hinge on new plant types that will allow producing human food in space.

Finally, there is another lesson we can learn from traditional farmers. Crops, the soil, and all of our natural resources are more than mere commodities that we can buy and sell like stocks. Will Rogers, a fellow Oklahoman, predated the present "sustainability" mood back in the 1930s when he told Congress:

'You see, folks, what we're learnin' today is that you can rob from nature same way you can rob from any individual. But it ain't just robbin from nature, its robbin from future generations."

Now you might say that that is a funny thing for an Oklahoma cowboy to say, but this was Will Rogers, whose mother, a Cherokee Indian, had taught him that sacredness and diversity go together. The reason that my own children named our farm in Georgia "Rivers of Time" was to honor a Native American concept that life is a continuum and those fundamental resources that nourish us must be allowed to flow onward to the future. We cannot, like the engineers on the Tigris and Euphrates, plug up the River of Time for future generations. Seeds must become as central and sacred to our modern cultures as they were and remain to the traditional peoples of the world who gave to all of humanity our "daily bread."

\section{References}

Nazarea-Sandoval, V. 1994. Memory banking: The cultural dimensions of biodiversity. (In press.)

Rhoades, R.E. 1982. The incredible potato. Natl. Geographic Mag. 161(5):668-694.

Rhoades, R.E. 1991. The world's food supply at risk. Natl. Geographic Mag. 179(4):74-105.

Rhoades, R.E. 1993. Corn: The golden grain. Natl. Geographic Mag. 181(3):92-117. 